\title{
The Essential Role of DCLK1 in Pathogenesis, Diagnostic Procedures and Prognostic Stratification of Colorectal Cancer
}

\author{
ARKADIUSZ GZIL ${ }^{1 *}$, ŁUKASZ SZYLBERG $^{1,2^{*}}$, DAMIAN JAWORSKI $^{1}$, \\ JOANNA DOMINIAK ${ }^{1}$, IZABELA ZARĘBSKA ${ }^{1}$ and DARIUSZ GRZANKA ${ }^{1}$ \\ ${ }^{1}$ Department of Clinical Pathomorphology, Collegium Medicum in Bydgoszcz, \\ Nicolaus Copernicus University in Torun, Bydgoszcz, Poland; \\ ${ }^{2}$ Department of Pathomorphology, Military Clinical Hospital, Bydgoszcz, Poland
}

\begin{abstract}
Colorectal cancer (CRC) is the second most prevalent type of cancer among males and the third among females. CRC recurrence and poor prognosis may be related to the prevalence of chemotherapy-resistant cancer stem cells (CSCs). Recent studies have indicated the role of doublecortin-like kinase 1 (DCLK1) protein as a marker of CSC in CRC. This review focuses on the role of DCLKI in CRC. Long-lived DCLK1-positive tuft cells can function as cancer-initiating cells. Numerous studies have shown DCLK1 overexpression to be significantly correlated with the stage of disease, the presence of metastasis and poor survival rate. DCLKI may also be used to identify patients at high risk and those with chemotherapy-resistant tumors. DCLK1-specific drugs are examined as potential cancer treatments.
\end{abstract}

Colorectal cancer (CRC) is the second most prevalent cancer type among males and the third among females. The 5-year relative survival rate for patients with CRC is $65 \%$ (1). The poor prognosis is related to metastasis, especially distant metastasis to the liver (2). Tumor recurrence and poor prognosis may be relevant to the prevalence of chemotherapy-resistant cancer stem cells (CSC) (3). Recent studies have shown that these cells are associated with maintaining the tumor cell population, metastatic processes

\footnotetext{
*These Authors contributed equally to this study.

Correspondence to: Arkadiusz Gzil, Department of Clinical Pathomorphology CM UMK, Sklodowskiej-Curie Str. 9, 85-094 Bydgoszcz, Poland. Tel: +48 525854200, Fax: +48 525854049, email: arkadiuszgzilresearch@gmail.com
}

Key Words: Colorectal cancer, DCLK1, cancer diagnostic factor, cancer prognostic factor, review. and chemotherapy resistance (4). CSCs have the ability for self-renewal and may initiate tumorigenesis. Circulating CSCs have been detected in the bloodstream of patients with cancer $(5,6)$. There is more and more evidence emphasizing the role of specific markers for CSC detection. They may also serve as targets for cancer therapy in the future. Several CSC markers, such as leucine-rich repeat-containing G-protein coupled receptor 5 (LGR5), CD44 and progastrin peptides have been identified so far (7). The role of selected CSC markers is presented in Table I.

Recent studies have indicated the role of doublecortin-like kinase 1 (DCLK1) as a potential CSC marker in several tumor types. DCLK1 expression was shown to be correlated with low survival rate in esophageal, breast, and renal cell carcinoma (8-10). DCLK1 ${ }^{+}$cells were also found in the gastrointestinal tract and were mostly expressed in the lower parts of intestinal crypt epithelium and crypt based columnar cells in normal intestine (11). The role of DCLK1 in CRC has also been highlighted. DCLK1 expression was upregulated in CRC and was associated with CRC metastasis and poor prognosis (12). The discovery of DCLK1 may be used in the future to identify patients at high risk, monitor recurrence and evaluate response to therapy. This protein may also serve as a therapeutic target to improve outcomes. Herein, the Authors focus on the role of DCLK1 in CRC.

\section{DCLK1 as an Important Factor in Colorectal Carcinogenesis}

DCLK1 was first described in the developing brain (3). It was important in neurogenesis, cortical development and migration of neurons especially during fetal development (4, 7). This protein is a serine/threonine-protein kinase which is associated with microtubules and its overexpression leads to their elongation. DCLK $1^{+}$cells were found in the health gastrointestinal tract in mice (11). Most of the DCLK $1^{+}$cells 
Table I. Significance of selected cancer stem cell markers (5, 8-12, 37, 38, 55-69).

\begin{tabular}{|c|c|c|c|c|c|}
\hline Marker & Protein & Description & Cancer & $\begin{array}{l}\text { Clinical implications of } \\
\text { overexpression }\end{array}$ & Future perspectives \\
\hline ANXA2 & Annexin A2 & $\begin{array}{l}\text { - Receptor for PG } \\
\text { - Important for effects of } \\
\text { PG on target cells }\end{array}$ & $\begin{array}{l}\text { - Colon } \\
\text { - Breast } \\
\text { - Pancreas } \\
\text { - Kidney } \\
\text { - Liver }\end{array}$ & $\begin{array}{l}\text { - Poor prognosis } \\
\text { - Drug resistance }\end{array}$ & - Therapeutic target \\
\hline CD44 & $\begin{array}{l}\text { Cluster of } \\
\text { differentiation } 44\end{array}$ & $\begin{array}{l}\text { - Transmembrane cell-surface } \\
\text { adhesion molecule } \\
\text { - Involved in tumor cell } \\
\text { adhesion and invasion }\end{array}$ & $\begin{array}{l}\text { - Colon } \\
\text { - Breast } \\
\text { - Head and neck }\end{array}$ & $\begin{array}{l}\text { - Usually poor prognosis } \\
\text { - Drug resistance }\end{array}$ & - Therapeutic target \\
\hline DCLK1 & $\begin{array}{l}\text { Doublecortin-like } \\
\text { kinase } 1\end{array}$ & $\begin{array}{l}\text { - Protein associated with } \\
\text { elongation of microtubules } \\
\text { - Present in the } \\
\text { gastrointestinal tract }\end{array}$ & $\begin{array}{l}\text { - Colon } \\
\text { - Breast } \\
\text { - Pancreas } \\
\text { - Kidney } \\
\text { - Esophagus }\end{array}$ & $\begin{array}{l}\text { - Poor prognosis } \\
\text { - Drug resistance }\end{array}$ & $\begin{array}{l}\text { - Therapeutic target } \\
\text { - Detection of DCLK1+ } \\
\text { cells in blood }\end{array}$ \\
\hline LGR5 & $\begin{array}{l}\text { Leucine-rich repeat- } \\
\text { containing G protein- } \\
\text { coupled receptor } 5\end{array}$ & $\begin{array}{l}\text { - Receptor for R-spondins } \\
\text { responsible for their } \\
\text { WNT-enhancing effects, } \\
\text { - Target of the WNT pathway }\end{array}$ & $\begin{array}{l}\text { - Colon } \\
\text { - Nervous system }\end{array}$ & - Poor prognosis & - Therapeutic target \\
\hline PG & Progastrin & $\begin{array}{l}\text { - Growth factor } \\
\text { - Ligand for ANXA2 }\end{array}$ & - Colon & $\begin{array}{l}\text { - Risk for developing } \\
\text { colorectal neoplasia }\end{array}$ & $\begin{array}{l}\text { - Detection of patients } \\
\text { with risk of neoplasms }\end{array}$ \\
\hline
\end{tabular}

of the gastrointestinal tract belonged to the tuft cell population and were postmitotic (13). A subset of intestinal and colonic DCLK $1^{+}$tuft cells was found to be long-lived, quiescent, regulated and contributed to a stem cell niche (14). Long-lived DCLK $1^{+}$tuft cells can function as cancerinitiating cells (15).

Recent studies showed that the inflammatory process may also lead to induction of colorectal tumorigenesis with secondary increase of DCLK1 at the cellular level (17-19). In the early stage of CRC carcinogenesis, the expression of DCLK1 seems to increase from low-grade adenomas with worsening severity of dysplasia $(18,19)$. Moreover, significantly higher DCLK1 expression levels were detected in CRC tissue than in normal colonic specimens, and DCLK1 silencing significantly inhibited cell migration, invasion, and sphere-forming potential (20). A large population of DCLK $1^{+}$tumor cells was present in cancer with mutation of adenomatous-polyposis-coli $(A P C)$ gene particularly in CRC (21). This attribute correlated with increased pluripotency and self-renewal ability of cancer cells $(21,22)$. However DCLK1 expression was infrequently detected in serrated tumors of the colorectum (23).

The expression of DCLK $1^{+}$CSCs was promoted by special AT-rich sequence-binding protein 2 (SATB2), RNAbinding motif containing protein 3 overexpression, $m i R-15 b$ and lymphoid enhancer-binding factor 1 (LEF1) (24-27). Prolactin also induced DCLK1 expression in CSCs by the modulation of NOTCH signaling (28).
Studies suggested that disorders with DCLK1 expression are caused by epigenetic alterations (29-31). Hypermethylation of the DCLK1 promoter was observed in $82 \%$ of primary CRC samples (30). The silencing of the $5^{\prime}(\alpha)$ promoter and transcript originating from the alternate $\beta$ promoter lead to translation of an incorrect, shorter polypeptide chain of DCLK1. This alternate DCLK1 protein seems to be a response to some form of oncogenic signaling during colon carcinogenesis (31). Sarkar et al. discovered that transcription factor forkhead box D3 (FOXD3) strongly inhibits the activity of the $\beta$ promoter, which caused the suppression of the expression of altered DCLK1 (32). Negative correlation between the levels of DCLK1 and FOXD3 was observed in pre-malignant colonic adenomas (32). In immunohistochemical examination, adenomatous polyps demonstrated higher staining for DCLK1 and significantly lower staining for FOXD3 (approximately 40\% and 10\%, respectively) in samples from patients who developed CRC within 15 years of polypectomy (32). Immunostaining for DCLK1 and FOXD3 was found in approximately 10\% and $40 \%$, respectively in adenomas of patients who remained disease-free in 15 years of follow-up (32). Hypermethylation of FOXD3 was also found in human colon cancer (33). This suggests the influence of loss of FOXD3 on DCLK1 expression, with consequent colonic cancer development. Altered DCLK1 was shown to regulate prosurvival signaling, including of catenin beta 1 (CTNNB1), transcription factor p65 (RELA), prostaglandin-endoperoxide synthase 1 (PTGS1)and prostaglandin-endoperoxide synthase 2 (PTGS2) (21). 


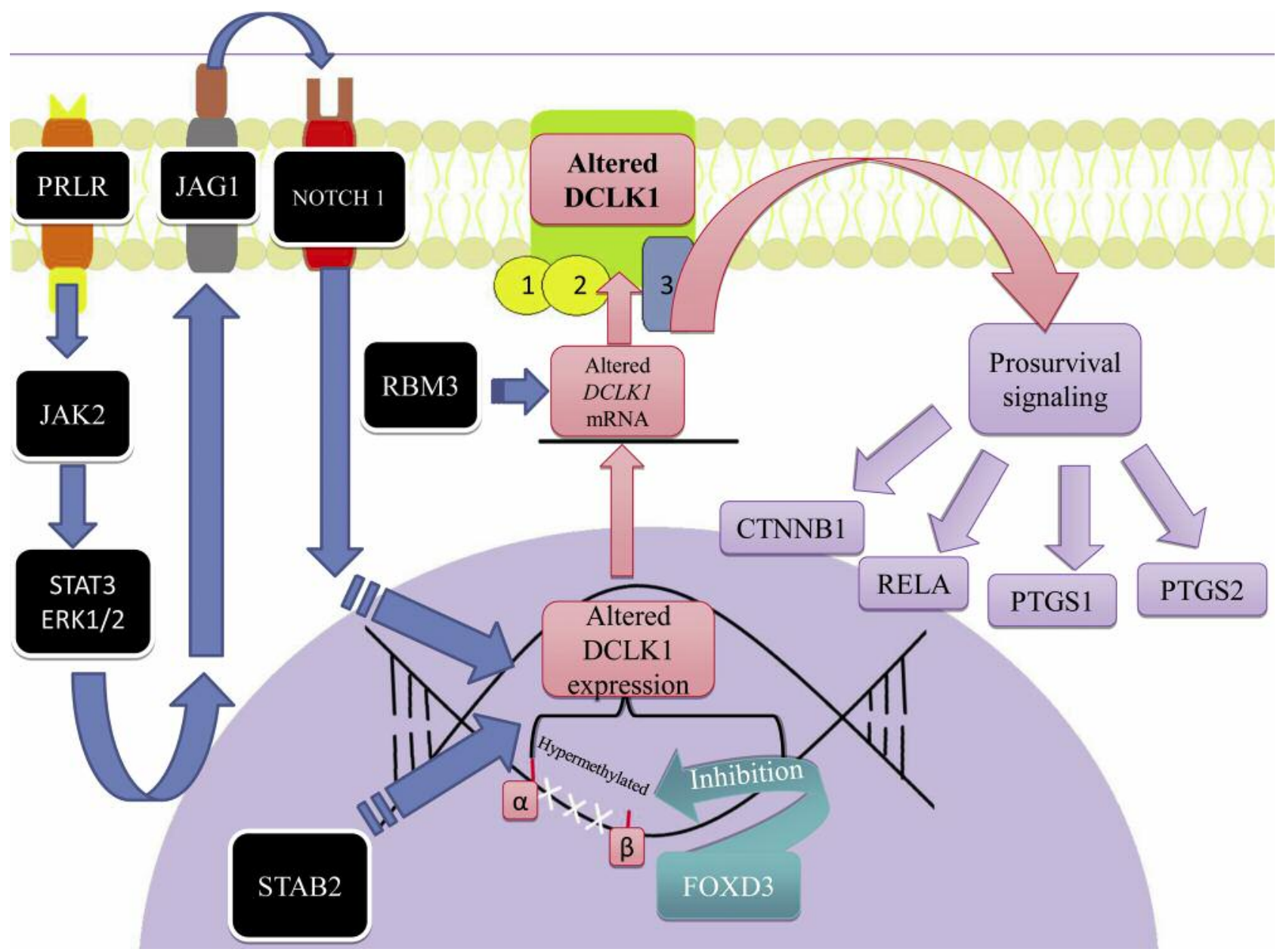

Figure 1. Molecular pathways associated with overexpression of doublecortin-like kinase 1 (DCLK1) (22, 26-32, 70, 71). Autocrine prolactin stimulates membrane prolactin receptor of cancer cells, which causes activation of cytoplasmic factor Janus kinase 2 (JAK2). Activated JAK2 triggers downstream factors, such as extracellular signal-regulated kinases 1 and 2 (ERK1/2) or signal transducer and activator of transcription 3 (STAT3), leading to overexpression of membrane protein JAG1 in cancer cells. JAG1 is a ligand of NOTCH receptor 1 (NOTCH1). NOTCH1 receptor stimulation by other cancer cells causes excitation of DCLK1 expression. Overexpression of alternate DCLK1 can also be induced by overexpression of transcription factor stabilin-1 (STAB2) in cancer cells. Transcription of altered DCLK1 begins from the $\beta$ promoter ( $\beta$ ) because of hypermethylation of the $\alpha$ promoter ( $\alpha$ ). forkhead box D3 (FOXD3) can inhibit $\beta$ promoter with lack of expression of altered DCLK1. In order to avoid degradation by cellular protective mechanisms, alternated mRNA of DCLK1 bind to RNA binding motif containing protein 3 (RBM3). Altered DCLK1 protein regulates prosurvival signaling including of catenin beta 1 (CTNNB1), transcription factor p65 (RELA), prostaglandinendoperoxide synthase 1 (PTGS1) and prostaglandin-endoperoxide synthase 2 (PTGS2). PRLR: prolactin receptor; RBM3: RNA-binding motif containing protein 3; 1: doublecortin domain DCX1; 2: doublecortin domain DCX2; 3: serinelthreonine kinase domain.

Additionally, knocking down $D C L K 1$ reduced tumor cell stemness and progression (21). Molecular pathways associated with DCLK1 overexpression are presented in Figure 1.

The epithelial-mesenchymal transition (EMT) is a biological process that allows a polarized epithelial cell to assume a mesenchymal cell phenotype, which includes enhanced migratory capacity and invasiveness (34). EMT phenotype development among CSCs can be caused by vimentin overexpression (35). Due to an increase of $\beta 1$-integrin and the loss of the junction protein E-cadherin, vimentin may mediate changes in cytoskeleton architecture (36). Studies have revealed the association between DCLK1 overexpression, an increased level of vimentin and reduced level of E-cadherin (12, $22,37)$. DCLK1 may consequently affect the EMT of CSCs.

\section{Diagnostic Opportunities in CRC Based on DCLK1}

Studies have suggested that CSCs are mainly associated with the invasive properties of tumors, such as metastasis, tumor progression, recurrence and resistance to treatment. Mirzaei 
Table II. Comparison of diagnostic methods for detecting doublecortin-like kinase 1 (DCLK1) (38, 39).

\begin{tabular}{lcccc}
\hline Method & Material & Target & Sensitivity (\%) & Specificity (\%) \\
\hline (q)RT-PCR & Peripheral blood & mRNA level of DCLK1 & 81 & 58 \\
ELISA & Peripheral blood & ccDCLK1 & 72.4 & 72.4 \\
\hline
\end{tabular}

(q)RT-PCR: Quantitative real-time reverse transcription-polymerase chain reaction; ELISA: enzyme-linked immunosorbent assay; ccDCLK1: circulating cellular DCLK1 protein.

et al. suggested it would be worth detecting CSCs in peripheral blood (PB) using specific markers (38). PB is a good source of material for investigating tumor markers because it benefits from non-invasiveness, simplicity of sampling, and accessibility (38). Mirzaei et al. showed overexpression of DCLK1 in PB of patients with CRC in comparison to a control group. The DCLK1 mRNA level was also found to be significantly higher in patients with more invasive and metastatic CRC (38). Using quantitative realtime reverse transcription-polymerase chain reaction (PCR), the mRNA level of DCLK1 as a CSC marker was assessed $(30,37,38)$. The results of the research showed a significant increase in DCLK1 mRNA level in PB of patients with CRC in comparison to controls (2.7-fold increase), with a sensitivity and specificity of $81 \%$ and $58 \%$, respectively (38).

Another method for measuring circulating tumor cells in blood uses immunofluorescence. It is based on assessing specific markers such as DCLK1 (5). This would also be useful as a non-invasive diagnostic procedure for screening patients at high risk for developing metastatic cancer or cancer relapse (5). DCLK $^{+}$circulating CSCs were detected in the blood of patients with CRC. The number of $\mathrm{DCLK}^{+}$cells was significantly higher in the blood of patients with CRC in comparison to that of patients scheduled for screening colonoscopy and was also correlated with tumor stage and grade (5). Using immunofluorescence, it might be possible to develop personalized treatment regimens for targeting and eliminating circulating CSCs in order to reduce the possibility of relapse or metastatic disease significantly and improve clinical results (5).

As described above, most methods are based on measurements of mRNA levels of CSC markers. However, Mirzaei et al. demonstrated that measurement of proteins as the final product of genes leads to more accurate results (39). They offered a method based on measuring circulating cellular DCLK1 protein using three immunoassay methods: immunePCR, proximity ligation assay, and enzyme-linked immunosorbent assay (39). The circulating cellular DCLK1 protein level shown by all three methods was significantly increased in $\mathrm{PB}$ of patients with CRC compared to the control group (1.82-, 2- and 1.74-fold increases, respectively). Moreover, a higher level of circulating cellular DCLK1 protein was also correlated with tumor stage, grade and lymphatic invasion (39). Comparing these three immunoassay methods:
immune-PCR with high sensitivity, proximity ligation assay with high specificity, and enzyme-linked immunosorbent assay with mid sensitivity and specificity and high reproducibility, it has been proven that the best method is an enzyme-linked immunosorbent assay because it is specific enough to evaluate DCLK1 protein expression (39). Differences between methods of detecting DCLK1 are presented in Table II. Therefore, measurement of the circulating cellular DCLK1 protein might have a diagnostic and prognostic role (39).

Another method is using quantitative methylation-specific PCR. This method is not for diagnosis, but may be useful for prognosis. This allows the assessment of hypermethylation of the DCLK1 core promoter (30). Hypermethylation of DCLK1 was observed in 134 out of 164 analyzed CRCs and in none of 106 samples of normal colorectal mucosa, resulting in a sensitivity and specificity of $82 \%$ and $100 \%$, respectively (30). It was noted that DCLK1 was down-regulated in 125 analyzed CRC samples in comparison to unchanged mucosa. Subsequently, a decrease in the DCLK1 expression of colorectal tumors was confirmed by quantitative real-time reverse transcription-PCR (30). Hypermethylation of DCLK1 promoter is a promising new epigenetic biomarker for CRC. It has also been shown that the progeny of the CSCs, which constitutes the greater part of the tumor, have reduced expression of DCLK1 in comparison to the normal mucosa. This is very important when considering whether DCLK1positive cells may be a weak point of CRC treatment and a promising therapeutic target (30).

The early identification of DCLK $1^{+}$CSCs may allow for selection of an appropriate treatment. It is possible to achieve good therapeutic effects by directly or indirectly targeting the DCLK ${ }^{+}$cells. Nakanishi et al. suggested that diphtheria toxin causes apoptosis only in the DCLK $1{ }^{+} \mathrm{CSCs}$, but not in the DCLK $1^{-}$cells (40). Interruption of delivery of the tumor progeny provided by DCLK $1^{+}$CSCs can cause tumor regression (37).

\section{Clinical Implications of DCLK1 Overexpression in Colorectal Cancer}

Numerous studies have shown that DCLK1 overexpression is significantly correlated with the stage of disease, the presence of metastasis and poor survival rate $(12,31,32,41-43)$. Gao 
et al. revealed the 5-year disease-specific survival in patients with low and high DCLK1 immunostaining to be $85.7 \%$ and $52.5 \%$, respectively (12). Gagliardi et al. proposed a scale to show the correlation between immunoreactivity of DCLK1 in CRC and prediction of clinical outcome. This scale is based on the intensity of staining (score 0-3) combined with the percentage of positive tissue staining (score 0-3), and was shown to have an accuracy of $68.9 \%$, a sensitivity of $64.3 \%$, and a specificity of $69.2 \%$ (41). A score of 5 or more correlated with $60 \%$ mortality of patients in a period of 4-37 months; those below $<4$ correlated with $25 \%$ mortality of patients in 11-70 months (41). However, the results of Dai et al. suggested that patients with high DCLK1 expression exhibited a significantly longer survival than did patients with low DCLK1 expression (44). This incompatibility should be solved in a future study.

Actual molecular biology knowledge suggests the importance of FOXD3 level in CRC development. The combined expression of DCLK1 and FOXD3 exhibited significant correlation with overall patient survival, but the correlation was not any more significant that with DCLK1 alone (32). On the other hand, the expression level of FOXD3 alone did not correlate with overall patient survival (32).

Mortality in CRC arises from distant metastases (2). Gao et al. revealed the role of DCLK1 in the metastatic process in CRC. From among studies analyzed, two revealed correlation between DCLK1 overexpression and the possible contribution of DCLK1 to the metastatic process. However, divergence in immunoreactivity for DCLK1 in both of these studies is significant. A study performed by Gao et al. showed DCLK overexpression by immunohistochemistry in all cases, while another study revealed the presence of immunoreactivity for DCLK1 in only $50 \%$ of investigated cases of metastatic CRC $(12,41)$.

Studies showed that a high level of DCLK1 mRNA correlated with advanced clinical stage and lymph node metastasis, but not with differentiation, location, gender, or age $(12,43)$. Higher DCLK1 mRNA level was also observed in patients after neoadjuvant chemoradiotherapy (43).

Another significant type of molecule is microRNA, which is small non-coding RNA molecule. MicroRNAs consist of stable sets of small non-coding RNA that regulate complex processes during carcinogenesis, such as stemless, EMT, expression of tumor-suppressor genes and oncogenes (4548). Weygant et al. investigated a 15-microRNA signature as a surrogate biomarker of DCLK1 biological activity in regard to recurrence of CRC. After approximately 75 months, the disease was found to recur in patients with a high-risk microRNA signature, corresponds high activity of DCLK1 in CRC cells (42). Low-risk microRNA signature, and thus low influence of DCLK1 on cellular pathways, was related to recurrence after approximately 150 months only in
$20 \%$ of cases (42). Every patient with a high-risk microRNA signature died within 100 months (42).

Chemotherapy-resistant CSCs are responsible for unsatisfactory response to treatment (5). DCLK1-specific drugs are being examined as a potential treatment possibility in hepatocellular, pancreatic and ovarian cancer (49-53). In the study of Suehiro et al. the combination of 5-fluorouracil and DCLK1 inhibitor was more effective in CRC compared to individual treatment with these substances separately (54).

The latest studies have revealed new options for specific treatment pathways against CSC via DCLK1. Because of the role of inflammation in DCLK1-related tumorigenesis, one study reported that the inhibition of the inflammatory cysteinyl leukotriene receptor 1 (CysLT1R) through its antagonist, montelukast, is beneficial in minimizing stemness in colorectal tissue, with a reduction in tumor size in association with reduced levels of DCLK1 (55).

Furthermore, Qiao et al. developed a nondrug delivery system by conjugating hyaluronic acid and grafting DCLK1 monoclonal antibody to the surface of poly(ethylene glycol)poly(D,L-lactide-co-glycolide) nanoparticles that is useful for targeting CSCs (56)

The LEF1/DCLK1 axis can be disrupted by niclosamide, which would impair the tumor-initiating and survival potential of CSCs (25). Another study revealed that siRNAmediated specific blockade of DCLK1 translation resulted in tumor growth arrest, corresponding with reduced expression of the oncogene $M Y C$ (57). The study of Osman et al. in addition suggested that Wnt family member 5A (WNT5A) agonist FOXY5 may complete the traditional adjuvant chemotherapy to which CSCs are resistant (58).

These findings could allow specific treatment against CSCs in CRC to be developed.

\section{Conclusion}

DCLK1 overexpression was significantly correlated with the stage of disease, the presence of metastasis and poor survival rate. Moreover, the present of DCLK1 in the PB of patients with CRC could suggest that this protein may act as a potential marker of therapy monitoring. DCLK1 may also be used to identify high-risk patients and those with chemotherapy-resistant tumors. DCLK1-specific drugs represent an innovative potential treatment for CRC.

\section{Funding}

This research received no specific grant from any funding agency in the public, commercial, or not-for-profit sectors.

\section{Conflicts of Interest}

The Authors declare that they have no conflict of interest in regard to this study. 


\section{Authors' Contributions}

All Authors of this work were committed to the selection of the theme and planning of article structure. Arkadiusz Gzil was responsible for research of literature about DCLK1-related molecular pathways in colorectal cancer and impact of DCLK1 on colorectal cancer carcinogesis, for formulating the section entitled 'DCLK1 as an Important Factor in Colorectal Carcinogenesis' and as a corresponding author for article submission. Łukasz Szylber revised the article draft by adding intellectual insights and provided critical advice, language correction and preparation of Figure 1. Damian Jaworski was responsible for research of literature about clinical data with regard to DCLK1 and DCLK1-target therapy by colorectal cancer, for formulating the section entitled 'Clinical Implications of DCLK1 Overexpression in Colorectal Cancer'. Joanna Dominiak was responsible for research of literature about diagnostic opportunities with regard to DCLK1 in colorectal cancer, for formulating the section entitled 'Diagnostic Opportunities in CRC Based on DCLK1' and preparing of Table II. Izabela Zarębska was responsible for research of literature about general information about colorectal cancer, cancer stem cells and role of DCLK1 in other neoplasm, for formulating the Introduction and preparing of Table I. Dariusz Grzanka revised the article draft by adding intellectual insights and provided critical advice, determining the value of work and control of progress of article preparation.

All Authors gave approval of the final version for submission.

\section{References}

1 Siegel RL, Miller KD and Jemal A: Cancer statistics. CA Cancer J Clin 66: 7-30, 2016. PMID: 26742998. DOI: 10.3322/ caac. 21332

2 Stein U and Schlag PM: Clinical, biological, and molecular aspects of metastasis in colorectal cancer. Recent Results Cancer Res 176: 61-80, 2007. PMID: 17607917. DOI: 10.1007/978-3540-46091-67

3 Dijkmans TF, van Hooijdonk LWA, Fitzsimons CP and Vreugdenhil E: The doublecortin gene family and disorders of neuronal structure. Cent Nerv Syst Agents Med Chem 10: 3246, 2010. PMID: 20236041. DOI: 10.2174/1871524107 90780118

4 Shu T, Tseng HC, Sapir T, Stern P, Zhou Y, Sanada K, Fischer A, Coquelle FM, Reiner O and Tsai LH: Doublecortin-like kinase controls neurogenesis by regulating mitotic spindles and M phase progression. Neuron 49: 25-39, 2006. PMID: 16387637. DOI: 10.1016/j.neuron.2005.10.039

5 Kantara C, O'Connell MR, Luthra G, Gajjar A, Sarkar S, Ullrich RL and Singh P: Methods for detecting circulating cancer stem cells (CCSCs) as a novel approach for diagnosis of colon cancer relapse/metastasis. Lab Investig 95: 100-112, 2015. PMID: 25347154. DOI: $10.1038 /$ labinvest.2014.133

6 Ning X, Shu J, Du Y, Ben Q and Li Z: Therapeutic strategies targeting cancer stem cells. Cancer Biol Ther 14: 295-303, 2013. PMID: 23358473. DOI: $10.4161 / \mathrm{cbt} .23622$

7 Chandrakesan P, Weygant N, May R, Qu D, Chinthalapally HR, Sureban SM, Ali N, Lightfoot SA, Umar S and Houchen CW: DCLK1 facilitates intestinal tumor growth via enhancing pluripotency and epithelial-mesenchymal transition. Oncotarget 5: 9269-9280, 2014. PMID: 25211188. DOI: 10.18632/ oncotarget. 2393
8 Vega KJ, May R, Sureban SM, Lightfoot SA, Qu D, Reed A, Weygant N, Ramanujam R, Souza R, Madhoun M, Whorton J, Anant S, Meltzer SJ and Houchen CW: Identification of the putative intestinal stem cell marker doublecortin and $\mathrm{CaM}$ kinase-like-1 in Barrett's esophagus and esophageal adenocarcinoma. J Gastroenterol Hepatol 27: 773-780, 2012. PMID: 21916995. DOI: 10.1111/j.1440-1746.2011.06928.x

9 Liu Y-H, Tsang JYS, Ni Y-B, Hlaing T, Chan S-K, Chan K-F, Ko C-W, Mujtaba SS and Tse GM: Doublecortin-like kinase 1 expression associates with breast cancer with neuroendocrine differentiation. Oncotarget 7: 1464-1476, 2016. PMID: 26621833. DOI: 10.18632/oncotarget.6386

10 Weygant N, Qu D, May R, Tierney RM, Berry WL, Zhao L, Agarwal S, Chandrakesan P, Chinthalapally HR, Murphy NT, Li JD, Sureban SM, Schlosser MJ, Tomasek JJ and Houchen CW: DCLK1 is a broadly dysregulated target against epithelialmesenchymal transition, focal adhesion, and stemness in clear cell renal carcinoma. Oncotarget 6: 2193-2205, 2015. PMID: 25605241. DOI: 10.18632/oncotarget.3059

11 May R, Sureban SM, Hoang N, Riehl TE, Lightfoot SA, Ramanujam R, Wyche JH, Anant S and Houchen CW: Doublecortin and CaM kinase-like-1 and leucine-rich-repeatcontaining G-protein-coupled receptor mark quiescent and cycling intestinal stem cells, respectively. Stem Cells 27: 25712579, 2009. PMID: 19676123. DOI: 10.1002/stem.193

12 Gao T, Wang M, Xu L, Wen T, Liu J and An G: DCLK1 is upregulated and associated with metastasis and prognosis in colorectal cancer. J Cancer Res Clin Oncol 142: 2131-2140, 2016. PMID: 27520310. DOI: 10.1007/s00432-016-2218-0

13 Gerbe F, Brulin B, Makrini L, Legraverend C and Jay P: DCAMKL-1 expression identifies tuft cells rather than stem cells in the adult mouse intestinal epithelium. Gastroenterology 137: 2179-2180, 2009. PMID: 19879217. DOI: 10.1053/ j.gastro.2009.06.072

14 Westphalen CB, Quante M and Wang TC: Functional implication of DCLK1 and DCLK1-expressing cells in cancer. Small GTPases 8: 164-171, 2017. PMID: 27458755. DOI: 10.1080/ 21541248.2016.1208792

15 Westphalen CB, Asfaha S, Hayakawa Y, Takemoto Y, Lukin DJ, Nuber AH, Brandtner A, Setlik W, Remotti H, Muley A, Chen X, May R, Houchen CW, Fox JG, Gershon MD, Quante M and Wang TC: Long-lived intestinal tuft cells serve as colon cancerinitiating cells. J Clin Invest 124: 1283-1295, 2014. PMID: 24487592. DOI: $10.1172 /$ JCI73434

16 Roy BC, Ahmed I, Ramalingam S, Jala V, Haribabu B, Ramamoorthy P, Ashcraft J, Valentino J, Anant S, Sampath V and Umar S: Co-localization of autophagy-related protein $\mathrm{p} 62$ with cancer stem cell marker DCLK1 may hamper DCLK1's elimination during colon cancer development and progression. Oncotarget 10: 2340-2354, 2019. PMID: 31040926. DOI: 10.18632/oncotarget.26684

17 Ahmed I, Roy BC, Raach RMT, Owens SM, Xia L, Anant S, Sampath V and Umar S: Enteric infection coupled with chronic Notch pathway inhibition alters colonic mucus composition leading to dysbiosis, barrier disruption and colitis. PLoS One 13: 1-20, 2018. PMID: 30383855. DOI: 10.1371/journal. pone.0206701

18 Wang X, Yang Y and Huycke MM: Commensal-infected macrophages induce dedifferentiation and reprogramming of epithelial cells during colorectal carcinogenesis. Oncotarget 8 : 
102176-102190, 2017. PMID: 29254234. DOI: 10.18632/ oncotarget. 22250

19 Takiyama A, Tanaka T, Kazama S, Nagata H, Kawai K, Hata K, Otani K, Nishikawa T, Sasaki K, Kaneko M, Emoto S, Murono $\mathrm{K}$, Takiyama $\mathrm{H}$ and Nozawa $\mathrm{H}$ : DCLK1 expression in colorectal polyps increases with the severity of dysplasia. In Vivo 32: 365 371, 2018. PMID: 29475922. DOI: 10.21873/invivo.11247

20 Mohammadi Y, Tavangar SM, Saidijam M, Amini R, Etemadi K, Karimi Dermani F and Najafi R: DCLK1 plays an important role in colorectal cancer tumorgenesis through the regulation of $m i R$ 200c. Biomed Pharmacother 103: 301-307, 2018. PMID: 29656186. DOI: 10.1016/j.biopha.2018.04.042

21 Chandrakesan P, Yao J, Qu D, May R, Weygant N, Ge Y, Ali N, Sureban SM, Gude M, Vega K, Bannerman-Menson E, Xia L, Bronze M, An G and Houchen CW: DCLK1, a tumor stem cell marker, regulates pro-survival signaling and self-renewal of intestinal tumor cells. Mol Cancer 16: 30, 2017. PMID: 28148261. DOI: 10.1186/s12943-017-0594-y

22 Chandrakesan P, Weygant N, May R, Qu D, Chinthalapally HR, Sureban SM, Ali N, Lightfoot SA, Umar S and Houchen CW: DCLK1 facilitates intestinal tumor growth via enhancing pluripotency and epithelial-mesenchymal transition. Oncotarget 5: 9269-9280, 2014. PMID: 25211188. DOI: 10.18632/ oncotarget. 2393

23 Morio K, Yashima K, Tamoto A, Hosoda K, Yamamoto S, Iwamoto T, Ueda N, Ikebuchi Y, Kawaguchi K, Harada K, Murawaki $\mathrm{Y}$ and Isomoto $\mathrm{H}$ : Expression of doublecortin and CaM kinase-like-1 protein in serrated neoplasia of the colorectum. Biomed Reports: 47-50, 2018. PMID: 29399338. DOI: $10.3892 / \mathrm{br} .2017 .1017$

24 Ji D, Zhan T, Li M, Yao Y, Jia J, Yi H, Qiao M, Xia J, Zhang Z, Ding H, Song C, Han Y and Gu J: Enhancement of sensitivity to chemo/radiation therapy by using miR-15b against DCLK1 in colorectal cancer. Stem Cell Reports 11: 1506-1522, 2018. PMID: 30449704. DOI: 10.1016/j.stemcr.2018.10.015

25 Park SY, Kim JY, Choi JH, Kim JH, Lee CJ, Singh P, Sarkar S, Baek JH and Nam JS: Inhibition of LEF1-mediated DCLK1 by niclosamide attenuates colorectal cancer stemness. Clin Cancer Res 25: 1415-1429, 2019. PMID: 30446587. DOI: 10.1158/ 1078-0432.CCR-18-1232

$26 \mathrm{Yu}$ W, Ma Y, Shankar S and Srivastava RK: SATB2/ $\beta-$ catenin/TCF-LEF pathway induces cellular transformation by generating cancer stem cells in colorectal cancer. Sci Rep 7: 10939, 2017. PMID: 28887549. DOI: 10.1038/s41598-017-05458-y

27 Venugopal A, Subramaniam D, Balmaceda J, Roy B, Dixon DA, Umar S, Weir SJ and Anant S: RNA binding protein RBM3 increases $\beta$-catenin signaling to increase stem cell characteristics in colorectal cancer cells. Mol Carcinog 55: 1503-1516, 2016. PMID: 26331352. DOI: $10.1002 / \mathrm{mc} .22404$

28 Neradugomma NK, Subramaniam D, Tawfik OW, Goffin V, Kumar TR, Jensen RA and Anant S: Prolactin signaling enhances colon cancer stemness by modulating Notch signaling in a JAK2-STAT3/ERK manner. Carcinogenesis 35: 795-806, 2014. PMID: 24265293. DOI: $10.1093 /$ carcin/bgt379

29 Singh P, O'Connell M and Shubhashish S: Epigenetic regulation of human DCLK-1 gene during colon-carcinogenesis: clinical and mechanistic implications. Stem Cell Investig 3: 51, 2016. PMID: 27777940. DOI: 10.21037/sci.2016.09.07

30 Vedeld HM, Skotheim RI, Lothe RA and Lind GE: The recently suggested intestinal cancer stem cell marker DCLK1 is an epigenetic biomarker for colorectal cancer. Epigenetics 9: 346350, 2014. PMID: 24384857. DOI: 10.4161/epi.27582

31 O'Connell MR, Sarkar S, Luthra GK, Okugawa Y, Toiyama Y, Gajjar AH, Qiu S, Goel A and Singh P: Epigenetic changes and alternate promoter usage by human colon cancers for expressing DCLK1-isoforms: Clinical implications. Sci Rep 5: 14983, 2015. PMID: 26447334. DOI: 10.1038/srep14983

32 Sarkar S, O'Connell MR, Okugawa Y, Lee BS, Toiyama Y, Kusunoki M, Daboval RD, Goel A and Singh P: FOXD3 regulates CSC marker, DCLK1-S, and invasive potential: Prognostic implications in colon cancer. Mol Cancer Res 15: 1678, 2017. PMID: 28851816. DOI: 10.1158/1541-7786.MCR17-0287

33 van Roon EH, Boot A, Dihal AA, Ernst RF, van Wezel T, Morreau $\mathrm{H}$ and Boer JM: BRAF mutation-specific promoter methylation of FOX genes in colorectal cancer. Clin Epigenetics 5: 2, 2013. PMID: 23324568. DOI: 10.1186/1868-7083-5-2

34 Kalluri $\mathrm{R}$ and Weinberg RA: The basics of epithelialmesenchymal transition. J Clin Invest 119: 1420-1428, 2009. PMID: 19487818. DOI: 10.1172/JCI39104

35 Harner-Foreman N, Vadakekolathu J, Laversin SA, Mathieu MG, Reeder S, Pockley AG, Rees RC and Boocock DJ: A novel spontaneous model of epithelial-mesenchymal transition (EMT) using a primary prostate cancer derived cell line demonstrating distinct stem-like characteristics. Sci Rep 7: 1-18, 2017. PMID: 28094783. DOI: 10.1038/srep40633

36 Liu C-Y, Lin H-H, Tang M-J and Wang Y-K: Vimentin contributes to epithelial -mesenchymal transition cancer cell mechanics by mediating cytoskeletal organization and focal adhesion maturation. Oncotarget 6: 15966-15983, 2015. PMID: 25965826. DOI: 10.18632 /oncotarget.3862

$37 \mathrm{Li} \mathrm{L}$ and Bellows CF: Doublecortin-like kinase 1 exhibits cancer stem cell-like characteristics in a human colon cancer cell line. Chin J Cancer Res 25: 134-142, 2013. PMID: 23592893. DOI: 10.3978/j.issn.1000-9604.2013.03.02

38 Mirzaei A, Tavoosidana G, Modarressi MH, Rad AA, Fazeli MS, Shirkoohi R, Tavakoli-Yaraki M and Madjd Z: Up-regulation of circulating cancer stem cell marker, DCLK1 but not LGR5, in chemoradiotherapy-treated colorectal cancer patients. Tumor Biol 36: 4801-4810, 2015. PMID: 26468984. DOI: 10.18632/ oncotarget.5808

39 Mirzaei A, Madjd Z, Kadijani AA, Tavakoli-Yaraki M, Modarresi MH, Verdi J, Akbari A and Tavoosidana G: Evaluation of circulating cellular DCLK1 protein, as the most promising colorectal cancer stem cell marker, using immunoassay based methods. Cancer Biomarkers 17: 301-311, 2016. PMID: 27802206. DOI: 10.3233/CBM-160642

40 Nakanishi Y, Seno H, Fukuoka A, Ueo T, Yamaga Y, Maruno T, Nakanishi N, Kanda K, Komekado H, Kawada M, Isomura A, Kawada K, Sakai Y, Yanagita M, Kageyama R, Kawaguchi Y, Taketo MM, Yonehara S and Chiba T: DCLK11 distinguishes between tumor and normal stem cells in the intestine. Nat Genet 45: 98-103, 2012. PMID: 23202126. DOI: 10.1038/ng.2481

41 Gagliardi G, Goswami M, Passera R and Bellows CF: DCLK1 immunoreactivity in colorectal neoplasia. Clin Exp Gastroenterol 5: 35-42, 2012. PMID: 22557932. DOI: 10.2147/CEG.S30281

42 Weygant N, Ge Y, Qu D, Kaddis JS, Berry WL, May R, Chandrakesan P, Bannerman-Menson E, Vega KJ, Tomasek JJ, Bronze MS, An G and Houchen CW: Survival of patients with gastrointestinal cancers can be predicted by a surrogate 
microRNA signature for cancer stem-like cells marked by DCLK1 kinase. Cancer Res 76: 4090-4099, 2016. PMID: 27287716. DOI: 10.1158/0008-5472.CAN-16-0029

43 Mirzaei A, Tavoosidana G, Rad AA, Rezaei F, Tavakoli-Yaraki M, Kadijani AA, Khalili E and Madjd Z: A new insight into cancer stem cell markers: A new insight into cancer stem cell markers: Could local and circulating cancer stem cell markers correlate in colorectal cancer? Tumour Biol 37: 2405-2414, 2016. PMID: 26383518. DOI: 10.1007/s13277-015-3989-7

44 Dai T, Hu Y, Lv F, Ozawa T, Sun X, Huang J, Han X, Kishi H, Muraguchi A and Jin A: Analysis of the clinical significance of DCLK $1+$ colorectal cancer using novel monoclonal antibodies against DCLK1. Onco Targets Ther 11: 5047-5057, 2018. PMID: 30174443. DOI: $10.2147 /$ OTT.S169928

45 Garofalo M, Romano G, Di Leva G, Nuovo G, Jeon Y-J, Ngankeu A, Sun J, Lovat F, Alder H, Condorelli G, Engelman JA, Ono M, Rho JK, Cascione L, Volinia S, Nephew KP and Croce CM: EGFR and MET receptor tyrosine kinase-altered microRNA expression induces tumorigenesis and gefitinib resistance in lung cancers. Nat Med 18: 74-82, 2012. PMID: 22157681. DOI: $10.1038 / \mathrm{nm} .2577$

$46 \mathrm{Lu} \mathrm{Y,} \mathrm{Govindan} \mathrm{R,} \mathrm{Wang} \mathrm{L,} \mathrm{Liu} \mathrm{P,} \mathrm{Goodgame} \mathrm{B,} \mathrm{Wen} \mathrm{W,}$ Sezhiyan A, Pfeifer J, Li Y, Hua X, Wang Y, Yang P and You M: MicroRNA profiling and prediction of recurrence/relapse-free survival in stage I lung cancer. Carcinogenesis 33: 1046-1054, 2012. PMID: 22331473. DOI: 10.1093/carcin/bgs 100

47 Nimmo RA and Slack FJ: An elegant miRror: microRNAs in stem cells, developmental timing and cancer. Chromosoma 118: 405-418, 2009. PMID: 19340450. DOI: 10.1007/s00412-009$0210-\mathrm{Z}$

48 Harner-Foreman N, Vadakekolathu J, Laversin SA, Mathieu MG, Reeder S, Pockley AG, Rees RC and Boocock DJ: A novel spontaneous model of epithelial-mesenchymal transition (EMT) using a primary prostate cancer derived cell line demonstrating distinct stem-like characteristics. Sci Rep 7: 40633, 2017. PMID: 28094783. DOI: $10.1038 /$ srep40633

$49 \mathrm{Wu}$ X, Ruan Y, Jiang H and Xu C: MicroRNA-424 inhibits cell migration, invasion, and epithelial-mesenchymal transition by downregulating doublecortin-like kinase 1 in ovarian clear cell carcinoma. Int J Biochem Cell Biol 85: 66-74, 2017. PMID: 28161486. DOI: 10.1016/j.biocel.2017.01.020

50 Nguyen CB, Kotturi H, Waris G, Mohammed A, Chandrakesan P, May R, Sureban S, Weygant N, Qu D, Rao CV, Dhanasekaran DN, Bronze MS, Houchen CW and Ali N: (Z)-3,5,4'Trimethoxystilbene limits hepatitis $\mathrm{c}$ and cancer pathophysiology by blocking microtubule dynamics and cell-cycle progression. Cancer Res 76: 4887-4896, 2016. PMID: 27287718. DOI: 10.1158/0008-5472.CAN-15-2722

51 Sureban SM, Madhoun MF, May R, Qu D, Ali N, Fazili J, Weygant N, Chandrakesan P, Ding K, Lightfoot SA and Houchen CW: Plasma DCLK1 is a marker of hepatocellular carcinoma (HCC): Targeting DCLK1 prevents HCC tumor xenograft growth via a microRNA-dependent mechanism. Oncotarget 6: 37200-37215, 2015. PMID: 26468984. DOI: 10.18632/oncotarget.5808

52 Wang W, Zhang H, Wang L, Zhang S and Tang M: miR-613 inhibits the growth and invasiveness of human hepatocellular carcinoma via targeting DCLK1. Biochem Biophys Res Commun 473: 987-992, 2016. PMID: 27049311. DOI: 10.1016/j.bbrc.2016.04.003
53 Rangarajan P, Subramaniam D, Paul S, Kwatra D, Palaniyandi K, Islam S, Harihar S, Ramalinagam S, Gutheil W, Putty S, Pradhan R, Padhye S, Welch DR, Anant S and Dhar A: Crocetinic acid inhibits hedgehog signaling to inhibit pancreatic cancer stem cells. Oncotarget 6: 27661-27673, 2015. PMID: 26317547. DOI: 10.18632 /oncotarget.4871

54 Suehiro Y, Takemoto Y, Nishimoto A, Ueno K, Shirasawa B, Tanaka T, Kugimiya N, Suga A, Harada E and Hamano K: DCLK1 inhibition cancels 5-FU-induced cell-cycle arrest and decreases cell survival in colorectal cancer. Anticancer Res 38: 6225-6230, 2018. PMID: 30396941. DOI: 10.21873/anticanres. 12977

55 Bellamkonda K, Satapathy SR, Douglas D, Chandrashekar N, Selvanesan BC, Liu M, Savari S, Jonsson G and Sjölander A: Montelukast, a CysLT1 receptor antagonist, reduces colon cancer stemness and tumor burden in a mouse xenograft model of human colon cancer. Cancer Lett 437: 13-24, 2018. PMID: 30144515. DOI: 10.1016/j.canlet.2018.08.019

56 Qiao S, Zhao Y, Geng S, Li Y, Hou X, Liu Y, Lin FH, Yao L and Tian W: A novel double-targeted nondrug delivery system for targeting cancer stem cells. Int J Nanomedicine 11: 6667-6678, 2016. PMID: 27994463. DOI: 10.2147/IJN.S116230

57 Sureban SM, May R, Ramalingam S, Subramaniam D, Natarajan G, Anant S and Houchen CW: Selective blockade of DCAMKL1 results in tumor growth arrest by a Let-7a microRNAdependent mechanism. Gastroenterology 137: 649-659.e2, 2009. PMID: 19445940. DOI: 10.1053/j.gastro.2009.05.004

58 Osman J, Bellamkonda K, Liu Q, Andersson T and Sjölander A: The WNT5A agonist FOXY5 reduces the number of colonic cancer stem cells in a xenograft mouse model of human colonic cancer. Anticancer Res 39: 1719-1728, 2019. PMID: 30952711. DOI: 10.21873 /anticanres.13278

59 Singh P, Sarkar S, Kantara C and Maxwell C: Progastrin peptides increase the risk of developing colonic tumors: Impact on colonic stem cells. Curr Colorectal Cancer Rep 8: 277-289, 2012. PMID: 23226720. DOI: 10.1007/s11888-012-0144-3

60 Bharadwaj A, Bydoun M, Holloway R and Waisman D: Annexin A2 heterotetramer: Structure and function. Int J Mol Sci 14: 62596305, 2013. PMID: 23519104. DOI: 10.3390/ijms 14036259

61 Park YS, Huh JW, Lee JH and Kim HR: shRNA against CD44 inhibits cell proliferation, invasion and migration, and promotes apoptosis of colon carcinoma cells. Oncol Rep 27: 339-346, 2012. PMID: 22076607. DOI: 10.3892/or.2011.1532

62 Louderbough JM V. and Schroeder JA: Understanding the dual nature of CD44 in breast cancer progression. Mol Cancer Res 9: 1573-1586, 2011. PMID: 21970856. DOI: 10.1158/15417786.MCR-11-0156

63 Chen J, Zhou J, Lu J, Xiong H, Shi X and Gong L: Significance of CD44 expression in head and neck cancer: A systemic review and meta-analysis. BMC Cancer 14: 15, 2014. PMID: 24410905. DOI: $10.1186 / 1471-2407-14-15$

64 Negi LM, Talegaonkar S, Jaggi M, Ahmad FJ, Iqbal Z and Khar RK: Role of CD44 in tumour progression and strategies for targeting. J Drug Target 20: 561-573, 2012. PMID: 22758394. DOI: $10.3109 / 1061186 X .2012 .702767$

65 Nishio K, Kimura K, Amano R, Nakata B, Yamazoe S, Ohira G, Miura K, Kametani N, Tanaka H, Muguruma K, Hirakawa K and Ohira M: Doublecortin and CaM kinase-like-1 as an independent prognostic factor in patients with resected pancreatic carcinoma. World J Gastroenterol 23: 5764-5772, 2017. PMID: 28883702. DOI: $10.3748 /$ wjg.v23.i31.5764 
66 Sarkar S, Popov VL, Stevenson HL, Lee BS, Obeid RA, Luthra G, Singh P and Author C: A novel antibody against cancer-stemcell biomarker, DCLK1-S, is potentially useful for assessing colon cancer risk after screening colonoscopy. Lab Invest 97: 1245-1261, 2017. PMID: 28414327. DOI: 10.1038/labinvest. 2017.40

67 Chandrakesan P, Yao J, Qu D, May R, Weygant N, Ge Y, Ali N, Sureban SM, Gude M, Vega K, Bannerman-Menson E, Xia L, Bronze M, An G and Houchen CW: DCLK1, a tumor stem cell marker, regulates pro-survival signaling and self-renewal of intestinal tumor cells. Mol Cancer 16: 30, 2017. PMID: 28148261. DOI: 10.1186/s12943-017-0594-y

68 De Lau W, Barker N, Low TY, Koo BK, Li VSW, Teunissen H, Kujala P, Haegebarth A, Peters PJ, Van De Wetering M, Stange DE, Van Es J, Guardavaccaro D, Schasfoort RBM, Mohri Y, Nishimori K, Mohammed S, Heck AJR and Clevers H: LGR5 homologues associate with WNT receptors and mediate Rspondin signalling. Nature 476: 293-297, 2011. PMID: 21727895. DOI: $10.1038 /$ nature 10337

69 Nakata S, Campos B, Bageritz J, Lorenzo Bermejo J, Becker N, Engel $\mathrm{F}$, Acker T, Momma S, Herold-Mende C, Lichter P, Radlwimmer B and Goidts V: LGR5 is a marker of poor prognosis in glioblastoma and is required for survival of brain cancer stem-like cells. Brain Pathol 23: 60-72, 2013. PMID: 22805276. DOI: $10.1111 /$ j.1750-3639.2012.00618.x

70 Hirsch D, Barker N, Mcneil N, Hu Y, Camps J, Mckinnon K, Clevers H, Ried T and Gaiser T: LGR5 positivity defines stemlike cells in colorectal cancer. Carcinogenesis 35: 849-858, 2014. PMID: 24282287. DOI: 10.1093/carcin/bgt377
71 Do C, Bertrand C, Palasse J, Delisle MB, Shulkes A, CohenJonathan-Moyal E, Ferrand A and Seva C: A new biomarker that predicts colonic neoplasia outcome in patients with hyperplastic colonic polyps. Cancer Prev Res 5: 675-684, 2012. PMID: 22366915. DOI: 10.1158/1940-6207.CAPR-11-0408

72 Singh $\mathrm{P}, \mathrm{Wu} \mathrm{H}$, Clark $\mathrm{C}$ and Owlia A: Annexin II binds progastrin and gastrin-like peptides, and mediates growth factor effects of autocrine and exogenous gastrins on colon cancer and intestinal epithelial cells. Oncogene 26: 425-440, 2007. PMID: 16832341. DOI: $10.1038 /$ sj.onc. 1209798

73 Sarkar S, Swiercz R, Kantara C, Hajjar KA and Singh P: Annexin A2 mediates Up-regulation of NF-kB, $\beta$-catenin, and stem cell in response to progastrin in mice and HEK-293 cells. Gastroenterology 140: 583-595, 2011. PMID: 20826156. DOI: $10.1053 /$ j.gastro.2010.08.054

74 Patel O, Dai W, Mentzel M, Griffin MDW, Serindoux J, Gay Y, Fischer S, Sterle S, Kropp A, Burns CJ, Ernst M, Buchert M and Lucet IS: Biochemical and structural insights into doublecortinlike kinase domain 1. Structure 24: 1550-1561, 2016. PMID: 27545623. DOI: $10.1016 /$ j.str.2016.07.008

75 Venugopal A, Subramaniam D, Balmaceda J, Roy B, Dixon DA, Umar S, Weir SJ and Anant S: RNA binding protein RBM3 increases $\beta$-catenin signaling to increase stem cell characteristics in colorectal cancer cells. Mol Carcinog 55: 1503-1516, 2016. PMID: 26331352. DOI: $10.1002 / \mathrm{mc} .22404$

Received April 25, 2019

Revised May 20, 2019

Accepted May 22, 2019 